\section{Evaluation of the Cervical Vertebrae Maturation Index in Lateral Cephalograms Taken in Different Head Positions}

Fernando César Torres ${ }^{1}$, Marcos Shinao Yamazaki², Renata Pilli Jóias ${ }^{3}$, Luiz Renato Paranhos ${ }^{4}$, Sigmar de Mello Rode ${ }^{3}$, Danilo Furquim Siqueira ${ }^{5}$, Acacio Fuziy ${ }^{1}$
'Department of Orthodontics, UNICID - University of São Paulo City, São Paulo, SP, Brazil ${ }^{2}$ Department of Orthodontics, UMESP - Methodist University of São Paulo, São Bernardo do Campo, SP, Brazil ${ }^{3}$ Department of Dental Materials and Prosthodontics, UNESP - Univ Estadual Paulista, São José dos Campos, SP, Brazil ${ }^{4}$ Department of Dentistry, UFS - Federal University of Sergipe, Lagarto, SE, Brazil ${ }^{5}$ Department of Health Sciences, USC - Sagrado Coração University, Bauru, SP, Brazil

Correspondence: Prof. Dr. Luiz Renato Paranhos. Rua Padre Álvares Pitangueira, 248, 49400-000 Lagarto, SE, Brasil. Tel.: +55-79-9116-1896. e-mail: paranhos@ortodontista.com.br

Key Words: cervical vertebrae, growth and development, cephalometry, Orthodontics.

\section{Introduction}

Starting malocclusions treatment in certain stages of pubertal growth may optimize the orthodontic treatment, allowing better outcomes, especially in cases involving the use of orthopedic appliances to redirection growth (1-5). In cases of orthognatic surgery or when osseointegrated implants are installed, it is important to estimate the end of skeletal maturation stage.

Several techniques are available to identify the growth stage. The use of hand and wrist or carpal radiographs, are popular methods of evaluating bone growth and maturation due to the large number of ossification centers in a relatively small area (6). Another well-known method for such kind of evaluation is the use of lateral cephalograms (6-8), which allows the morphological analysis of $\mathrm{C} 2, \mathrm{C} 3$ and $\mathrm{C} 4$ vertebrae. Some authors suggested a method of percentage of pubertal growth expectation, evaluating the cervical vertebrae maturation index (CVMI) (9). Other authors $(1,2)$ related the vertebrae morphology to the pubertal growth spurt (PGS) in years.

When cephalometric analyses are made, it is important to standardize the patient's head position while the radiograph is taken, to avoid variations in tracing that might impair the reliability of measurements and interfere with the diagnosis. Studies indicate the natural head position (NHP) $(10,11)$ because it may be easily reproduced $(10-13)$.
Considering that the morphology of cervical vertebrae may be an indicator of the skeletal development of the individual, this study analyzed if the upward or downward head inclination during acquisition of lateral cephalogram might interfere with growth prediction, by evaluation of the cervical vertebrae maturation index (CVMI). The interest of this study is to evaluate until which point it is necessary to take another lateral cephalogram in case of positioning errors, which would expose patients to more radiation.

\section{Material and Methods}

This study was approved by UMESP's Institutional Review Board UMESP, protocol \#303695-09.

The study was conducted on 147 lateral cephalograms obtained from 49 patients, 26 females and 23 males, aged 9 to 15 years. Criteria of inclusion were individuals who needed lateral radiographs for orthodontic treatment, with no distinction of gender and in growth age. Pregnant individuals, or with postural problems, especially in cervical region, were excluded. The X-ray equipment (Rotograph Plus; Villa Sistemi Medicali Spa, Buccinasco, Italy) was used at $80 \mathrm{Kpv}$ and $10 \mathrm{~mA}$, with a focal distance of 1.52 $\mathrm{m}$, and exposure time of $1.3 \mathrm{~s}$. Each patient was submitted to three cephalograms, namely in NHP, NHP with upward $15^{\circ}$ inclination (NHP-Up) and NHP with downward $15^{\circ}$ inclination (NHP-Down). 
For acquisition of cephalograms in NHP, the patients were instructed to stand upright with the feet approximately $10 \mathrm{~cm}$ apart, holding a $1 \mathrm{~kg}$ weight in each hand and looking at a mirror (70 $\mathrm{cm}$ high and $40 \mathrm{~cm}$ wide), positioned at $1.40 \mathrm{~m}$ in front of them (11). The cephalostat ear rods were gently positioned in the entrance of auditory meatuses to avoid head rotation (12).

To standardize the patient's head positioning in NHP, NHP-Up and NHP-Down, a sheet was designed with a line on the horizontal plane, representing the NHP; one $15^{\circ}$ above it, representing the NHP-Up; and the other $15^{\circ}$ below it, for NHP-Down. These angles had their vertices at a point coinciding with the ear rods, standardized for all individuals. At each point, the Subnasale point (Sn) was marked using a ball-point pen. Each individual was positioned in NHP to acquire the first lateral cephalogram. The central line of the horizontal planes was positioned at the level of point Sn, with the aid of a ruler. Following, the patient was instructed to lift the head to acquire radiograph in NHP-Up, so that the ruler in point Sn would touch the line $15^{\circ}$ above the horizontal line. Then, the radiograph was taken in NHP-Down, with the ruler tangent to point Sn and coinciding with the line $15^{\circ}$ below (Fig. 1). The respective radiographs are shown in Figure 2.

All radiographs were numbered and identified in NHP, NHP-Up and NHP-Down for evaluation. The three previously calibrated examiners (Ex1, Ex2 and Ex3), visually classified the CVMI stage, as proposed by Bacceti et al. (2), individually, for the three types of positioning, starting with cephalograms in NHP followed by NHP-Up and NHP-Down.

The radiographs were analyzed in a dark room on a film viewer. A dark mask was used to cover the radiographs, preventing the observation of structures other than the vertebrae $\mathrm{C} 2, \mathrm{C} 3$ and $\mathrm{C} 4$ (Fig. 3).
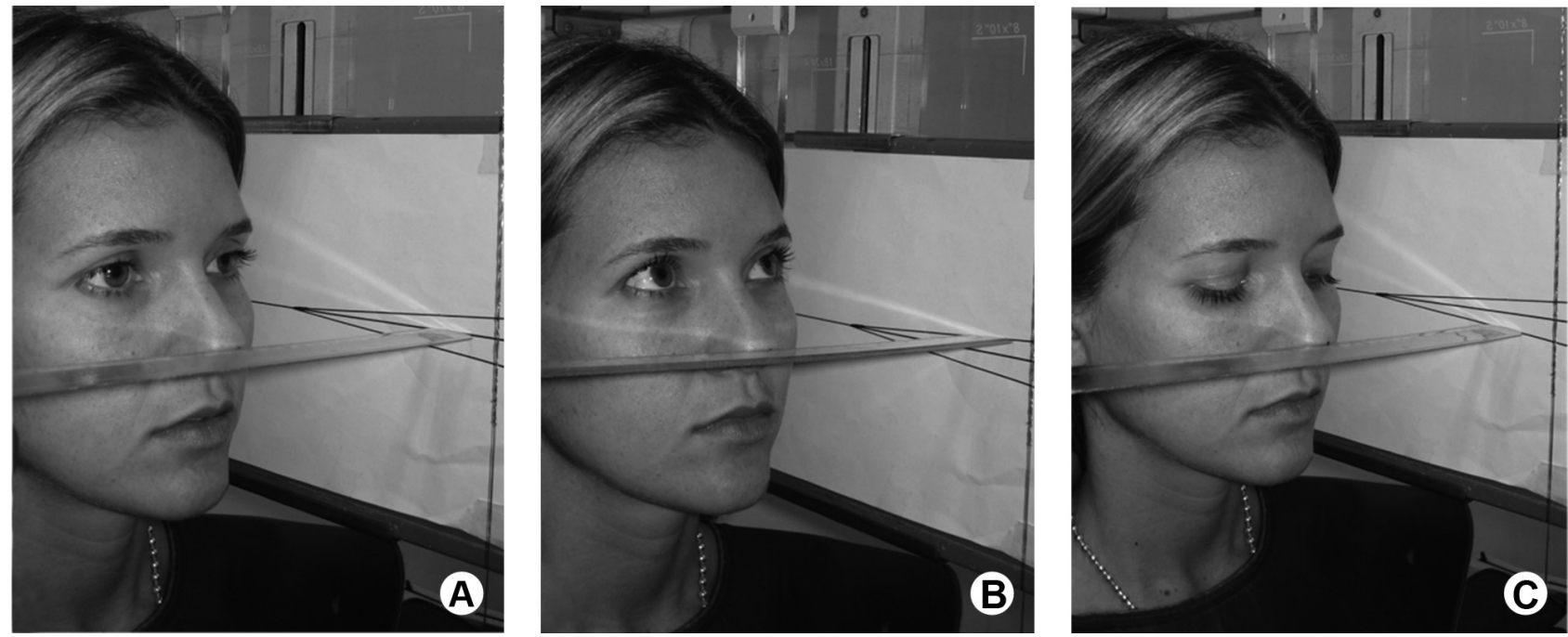

Figure 1. Patient positioning for acquisition of lateral cephalograms in: A) NHP; B) NHP-Up; and C) NHP-Down.
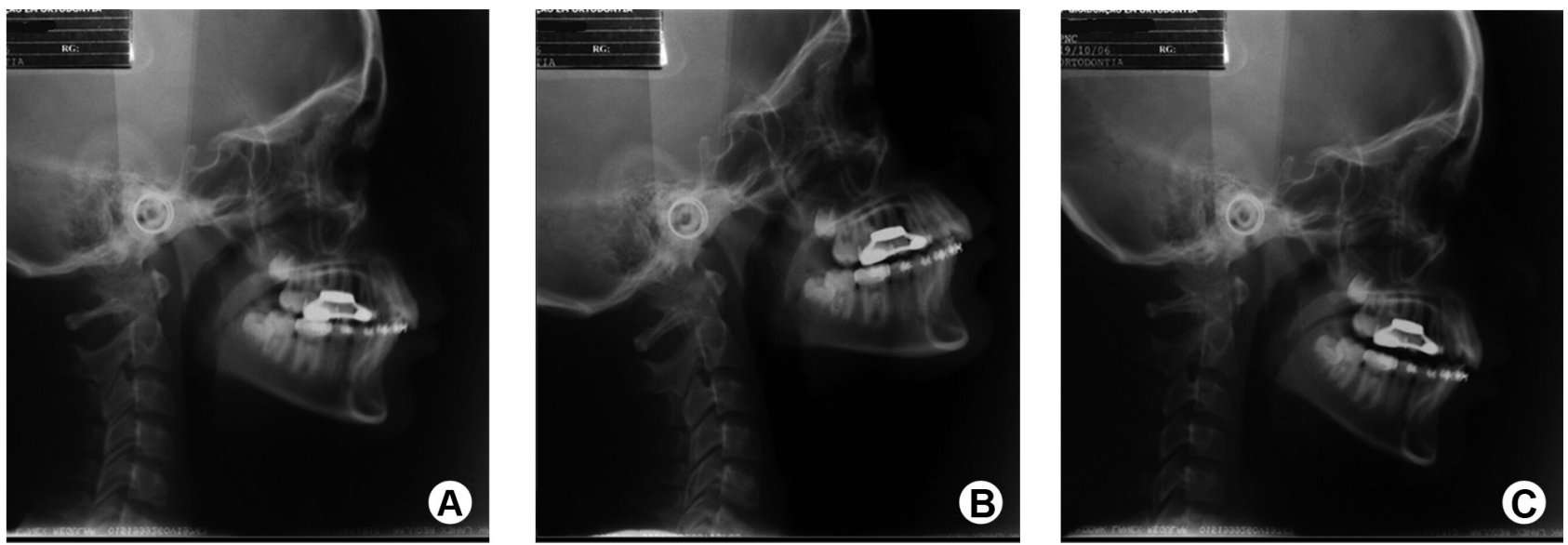

Figure 2. Lateral cephalograms taken in: A) NHP; B) NHP-Up; and C) NHP-Down. 
The method error was analyzed in 30\% of randomly selected radiographs, with application of the weighed Kappa test $\left(\mathrm{Kappa}_{\mathrm{w}}\right)$ to verify the inter-examiner agreement and degree of agreement between the three classification methods (NHP, NHP-Up and NHP-Down).

\section{Results}

There was a tendency of NHP-Up and NHP-Down to show higher scores of maturation stage, underestimating the growth potential of the individual. Table 1 reveals that the agreement among examiners was greater in NHP.

\section{Discussion}

The development stage of an individual may be analyzed by bone maturation, which evaluates the advanced increase of certain ossification centers $(14,15)$. Among the methods for quantification of remaining growth, analysis of the degree of skeletal maturation by direct observation of carpal radiograph or maturation of cervical vertebrae observed on lateral cephalograms has shown to be effective and reliable (1-3,16-18).

Knowing the growth and maturation stage of an individual facilitates the diagnosis and choice for the most adequate treatment, especially when orthopedic therapy is indicated $(4,5,22)$, which tends to present less expressive outcomes when performed in the final period of puberty, compared to the growth peak $(4,5,22)$.

Even though some authors (23) criticize the utilization of CVMI, claiming failures in the prediction of mandibular growth spurt, the designers of this method (2) highlight the usefulness of CVMI to determine the maturation stage of the patient $(2,3)$. One of the main advantages of this method, is the fact that lateral cephalometric radiographs are almost always present in orthodontic documentation, as they are used for treatment planning. This is important to follow the principle of minimum exposure of the patient to $X$-rays, obtaining, at the same time, the maximum of resources for an adequate diagnosis.

Adjustment of the patient head in the cephalostat ceased to be a concern for clinicians when it was realized that NHP might be advantageous to evaluate the facial profile (8). The standardized position was not desirable anymore in lateral cephalograms because it does not

Table 1. Evaluation of inter-examiner agreement of CVMl in NHP, NHP-Up and NHP-Down

\begin{tabular}{|c|c|c|c|c|}
\hline & Agreement & \% agreement & $\mathrm{Kappa}_{\mathrm{w}}$ & Interpretation \\
\hline \multirow{4}{*}{ NHP } & EX1 1 EX2 & 87.80 & 0.89 & almost perfect \\
\hline & EX1 1 EX3 & 71.40 & 0.79 & substantial \\
\hline & EX2 $\times$ EX3 & 73.5 & 0.78 & substantial \\
\hline & Mean & 77.60 & 0.82 & almost perfect \\
\hline \multirow{4}{*}{ NHP-Up } & EX1 1 EX2 & 81.5 & 0.83 & almost perfect \\
\hline & EX1 1 EX3 & 51.00 & 0.65 & substantial \\
\hline & EX2 $x$ EX3 & 49.00 & 0.61 & substantial \\
\hline & Mean & 60.05 & 0.70 & substantial \\
\hline \multirow{4}{*}{$\begin{array}{l}\text { NHP- } \\
\text { Down }\end{array}$} & EX1 1 EX2 & 79.60 & 0.87 & almost perfect \\
\hline & EX1 1 EX3 & 53.10 & 0.58 & moderate \\
\hline & EX2 $\times$ EX3 & 38.80 & 0.41 & moderate \\
\hline & Mean & 57.20 & 0.62 & substantial \\
\hline
\end{tabular}

Poor: <0.00; Slight: 0.00-0.20; Fair: 0.21-0.40; Moderate: 0.41-0.60 Substantial: 0.61-0.80; Almost Perfect: 0.81-1.00.
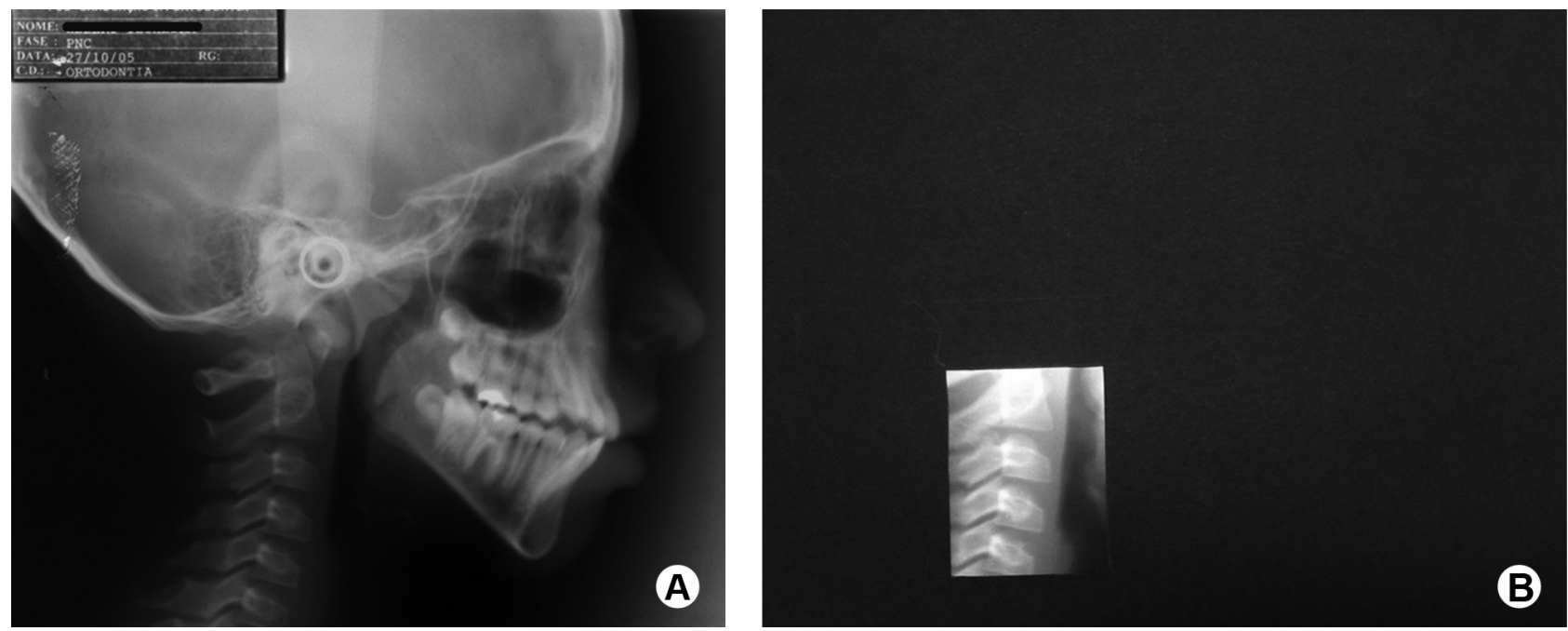

Figure 3. A: Lateral cephalogram. B: Dark mask used to cover the cephalograms during classification of the growth stage by analysis of cervical vertebrae. 
accurately represent the craniocervical posture, which may often be atypical because of some facial deformity and because a forced position in the cephalostat might mask the actual conformation of the soft tissue profile (24).

Since lateral cephalograms are performed by several operators in different radiology centers in the world, this study questioned if upward or downward alterations in the natural head position might cause errors in the evaluation of the bone maturation stage, when ossification of cervical vertebrae is observed on these radiographs. The importance of such study is to verify if it is necessary to take another lateral cephalogram in case of positioning errors. This would expose patients to more radiation, but it may be necessary to obtain a more accurate diagnosis of the growth stage.

Comparison of the cervical vertebrae maturation index (CVMI) on lateral cephalograms obtained in different positions revealed greater agreement between NHP-Up and NHP-Down. However, this does not represent the accuracy of these methods, yet is probably a coincidence of errors, since the "gold standard", i.e. the group acting as ideal parameter would be the cephalograms taken in NHP, because studies aimed at defining the maturation by analysis of vertebrae characteristics are mostly conducted on radiographs taken in the ideal position. When the NHP was compared to NHP-Up and NHP-Down, there was a tendency of both NHP-Up and NHP-Down to show higher scores, underestimating the growth potential of the individual. The fact that NHP-Up and NHP-Down indicate a more advanced stage of patient maturation may clinically influence the type of treatment indicated for the patient.

Concerning the consensus between examiners for growth prediction, Table 1 reveals that the agreement was greater in NHP. This may be explained by the calibration of examiners, which was based on a study (2) conducted on cephalograms without errors in head positioning. This may indicate that analysis of CVMI in cephalograms with positioning errors may not be adequate, especially using a criterion designed for evaluation of cephalograms taken in NHP. However, some cephalometric studies (19-21) advocate that alterations during acquisition of lateral cephalograms due to incorrect patient positioning, such as head rotations or inclinations, are clinically acceptable during the evaluation. The use of cephalograms with similar errors as those evaluated in this study should be associated to some other method of growth prediction for a more accurate evaluation of the CVMI, such as the utilization of carpal or thumb radiographs. Otherwise, the probable underestimation of the growth potential of the individual should be considered, according to the present results.

It may be concluded that the evaluations performed on cephalograms with positioning errors, with $15^{\circ}$ upward head inclination (NHP-Up) and with $15^{\circ}$ downward head inclination (NHP-Down), presented higher scores, indicating that the individuals would be in a more advanced growth stage, which might lead to underestimation of the residual growth potential of the patient. Evaluation of the CVMI on lateral cephalograms in NHP was more standardized between examiners, being probably more reliable for growth prediction compared to evaluation in NHP-Up and NHP-Down.

\section{Resumo}

0 objetivo deste estudo foi avaliar se a inclinação da cabeça para cima ou para baixo interfere na determinação do estágio de crescimento por meio do Índice de maturação das vértebras cervicais (IMVC), verificando a acurácia deste método de diagnóstico, quando as radiografias são tomadas com erros. Quarenta e nove pacientes, 26 do gênero feminino e 23 do masculino, entre 9 e 15 anos de idade, foram submetidos a 3 telerradiografias em norma lateral: posição natural de cabeça (PNC), cabeça inclinada $15^{\circ}$ para cima (PNC-alta), e $15^{\circ}$ para baixo (PNC-baixa). Três examinadores avaliaram o IMVC nas 147 telerradiografias. A concordância entre os examinadores foi alta na avaliação das telerradiografias obtidas em PNC. 0 teste Kappa revelou concordância moderada a substancial entre PNC e PNC-alta e entre PNC e PNC-baixa. Houve concordância significante entre PNC-alta e PNC-baixa. Pode-se concluir que a avaliação do IMVC em telerradiografias obtidas em PNC difere em comparação com as radiografias tomadas com inclinações. Tanto PNC-alta quanto PNC-baixa demonstraram maior discordância na interpretação entre os examinadores, uma vez que o método de avaliação não foi preconizado para telerradiografias com erros de posicionamento.

\section{References}

1. Bacceti T, Franchi L, McNamara Jr. JA. An improved version of the cervical vertebrae maturation (CVM) method for the assessment of mandibular growth. Angle Orthod 2002;72:316-323.

2. Bacceti T, Franchi L, McNamara Jr. JA. The cervical vertebrae maturation (CVM) method for the assessment of optimal treatment timing in dentofacial orthopedics. Semin Orthod 2005;11:119-129.

3. Franchi L, Bacetti T, McNamara Jr J.A. Mandibular growth as related to cervical vertebral maturation and body height. Am J Orthod Dentofacial Orthop 2000;118:335-340.

4. Mito T, Sato K, Mitani H. Cervical vertebral bone age in girls. Am J Orthod Dentofacial Orthop 2002;122:380-385.

5. Pancherz $H$, Hägg U. Dentofacial orthopedics in relation to somatic maturation. Am J Orthod 1985;88:273-287.

6. Aguiar LB, Caldas MP, Haiter Neto F, Ambrosano GM. A methodology to measure cervical vertebral bone maturation in a sample from lowincome children. Braz Dent J 2013;24:30-34.

7. Armond MC, Generoso R, Falci SG, Ramos-Jorge ML, Marques LS. Skeletal maturation of the cervical vertebrae: association with various types of malocclusion. Braz Oral Res 2012;26:145-150.

8. Broadbent H. A new x-ray technique and its application to orthodontia. Angle Orthod 1931;1:45-66.

9. Hassel B, Farman AG. Skeletal maturation evaluation using cervical vertebrae. Am J Orthod Dentofacial Orthop 1995;107:58-66.

10. Halazonetis DJ. Estimated natural head position and facial morphology. Am J Orthod Dentofacial Orthop 2001;121:364-368.

11. Moorrees CFA, Kean MR. Natural head position, a basic consideration in the interpretation of cephalometric radiographs. Am J Physiol Anthropol 1958;16:213-234.

12. Cooke MS, Wei SHY. The reproducibility of natural head posture: a methodological study. Am J Orthod Dentofacial Orthop 1988;93:180188.

13. Leitão $P$, Nanda RS. Relationship of natural head position to craniofacial morphology. Am J Orthod Dentofacial Orthop 2000;117:406-417.

14. Almeida-Pedrin RR, Tavano 0, Almeida RR, Ramos AD, Musegante 
$J C N$. Agenesis prevalence of the adductor sesamoid of the thumb in Brazilian adults. R Dental Press Ortod Ortop Facial 2008;13:86-91.

15. Silva Filho $0 G$, Sampaio LL, Souza Freitas JA. Evaluation of the effectiveness of an alternative simplified method to determine bone age. Ortodontia 1992;25:21-36.

16. Franchi L, Bacetti T, Toffol LD, Polimeni A, Cozza P. Phases of the dentition for the assessment of skeletal maturity: A diagnostic performance study. Am J Orthod Dentofacial Orthop 2008;133:395400.

17. Garcia-Fernandez $\mathrm{P}$, Torre $\mathrm{H}$, Flores $\mathrm{L}$, Rea J. The cervical vertebrae as maturation indicators. J Clin Orthod 1998;32:221-225.

18. Damian MF, Woithchunas FE, Cericato GO, Cechinato F, Moro G, Massochin ME, et al.. Reliability and correlation analysis of two skeletal maturation evaluation indexes: hand-wrist index and cervical vertebrae index. R Dental Press Ortod Ortop Facial 2006;11:110-120.

19. Ahlqvist J, Eliasson $S$, Welander U. The effect of projection errors on angular measurements in cephalometry. Eur J Orthod 1988;10:353361 .
20. Negreiros PE, Siqueira VCV. The effect of the alteration the natural head position (NHP) on the cephalometric measurements R Dental Press Ortod Ortop Facial 2004;9:59-76.

21. Peng $\mathrm{L}$, Cooke MS. Fifteen-year reproducibility of natural head posture: a longitudinal study. Am J Orthod Dentofacial Orthop 1999;116:82-85.

22. Hägg $U$, Pancherz H. Dentofacial orthopedics in relation to chronological age, growth period and skeletal development an analysis of 72 male patients with Class II division 1 malocclusion treated with Herbst appliance. Eur J Orthod 1988;10:169-176.

23. Gabriel DB, Southard KA, Qian F, Marshall SD, Franciscus RG, Southard TE. Cervical vertebrae maturation method: Poor reproducibility. Am J Orthod Dentofacial Orthop 2009;136:478.e.1-478.e.7.

24. Goldreich HN, Martins JCR, Martins LP, Sakima PR. A note on cephalometric error. Rev Dental Press Ortod Ortop Facial 1998;3:81-90.

Received April 17, 2013 Accepted August 23, 13 